\title{
Guru Honorer dalam Lingkaran Ketidakadilan
}

\author{
Gagan Aditya Fauzan \\ Program Studi Magister Studi Pembangunan, Sekolah Arsitektur Perencanaan dan Pengembangan Kebijakan, Institut \\ Teknologi Bandung \\ Jl. Ganesa No. 10, Bandung, Jawa Barat \\ gaganaditya197@gmail.com
}

\begin{abstract}
This study aims to examine the value of justice for honorary teachers in the world of work and highlight various policies and issues that have strengthened in recent years from an ethical, legal, and human rights perspective. The method in this study is a qualitative method by conducting a literature review. The basic paradigm adopted is Justice as Fairness proposed by John Rawls. Sources of data that are used as references are books, secondary data, observations, and legislation related to research issues with the main reference book being A Theory of Justice as the result of John Rawls's thinking. This research is expected to provide an overview of the reality experienced by honorary teachers in the world of work, provide moral support for the struggle of honorary teachers in Indonesia, and insert an ethical perspective on the problems of honorary teachers in Indonesia. Some of the findings in this study are that the Ministry of Education and Culture as the institution that oversees honorary teachers creates a condition of circumstances of justice where it is necessary to apply the principles of social justice to create social cooperation, as well as a fair distribution of primary values so that it does not cause economic inequality and can fulfill life. worthy. Besides being ethically unfair, the legal perspective also shows that there are still many parts of the law that have not been reflected on honorary teachers as workers.
\end{abstract}

Keywords: John Rawls Principles of Justice, Honorary Teacher, Honorary Teacher Wages, Law, Human Rights

\begin{abstract}
Abstrak
Penelitian ini bertujuan untuk mengkaji nilai keadilan bagi guru honorer dalam dunia kerja dan menyoroti berbagai kebijakan serta isu yang menguat dalam beberapa tahun terakhir dalam perspektif etis, hukum, dan HAM. Metode dalam penelitian ini adalah metode kualitatif dengan melakukan kajian pustaka. Adapun paradigma dasar yang dianut adalah Justice as Fairness yang dikemukakan oleh John Rawls. Sumber data yang menjadi acuan adalah buku, data sekunder, observasi, dan perundang-undangan yang terkait dengan isu penelitian dengan buku acuan utama adalah A Theory of Justice hasil pemikiran John Rawls. Penelitian ini diharapkan memberikan gambaran mengenai realita yang dialami guru honorer dalam dunia kerja, memberikan dukungan moral terhadap perjuangan guru honorer di Indonesia, serta menyisipkan perspektif etis dalam permasalahan guru honorer di Indonesia. Adapun beberapa temuan dalam penelitian ini adalah Kemendikbud sebagai lembaga yang menaungi guru honorer menciptakan sebuah kondisi circumstances of justice dimana diperlukan penerapan prinsip-prinsip keadilan sosial untuk menciptakan kerjasama sosial, serta pendistribusian nilai-nilai primer yang adil sehingga tidak menimbulkan ketimpangan ekonomi dan dapat terpenuhinya kehidupan yang layak. Selain tidak adil secara etis, perspektif hukum juga menunjukan bahwa masih banyak bagian undang-undang yang belum direfleksian kepada guru honorer sebagai tenaga kerja.
\end{abstract}

Kata kunci: Prinsip Keadilan John Rawls, Guru Honorer, Upah Guru Honorer, Hukum, Hak Asasi Manusia

Copyright (c) 2021 Gagan Aditya Fauzan

Corresponding author: Gagan Aditya Fauzan

Email Address: gaganaditya197@gmail.com (Jl. Ganesa No. 10, Bandung, Jawa Barat)

Received 01 December, Accepted 13 December 2021, Published 13 December 2021

\section{PENDAHULUAN}

Salah satu yang menjadi cita-cita bangsa Indonesia adalah mencerdaskan kehidupan bangsa agar menjadi bangsa yang maju, adil, dan makmur. Kualitas pendidikan merupakan salah satu indikator maju tidaknya suatu negara. Bagi bangsa yang maju pendidikan adalah sebuah kebutuhan prioritas, sehingga pendidikan memiliki posisi sejajar dengan aspek-aspek vital lain dalam 
pemerintahan. Hal ini sejalan dengan yang diungkapkan oleh Mahatma Ghandi (Rani, 2010) bahwa pendidikan penting baik bagi laki-laki maupun perempuan sebagai sumber pengembangan kepribadian manusia yang seimbang. Sedangkan definisi pendidikan secara keseluruhan adalah pembelajaran pengetahuan, keterampilan, dan kebiasaan sekelompok orang yang diturunkan dari satu generasi ke generasi berikutnya melalui pelatihan, pengajaran, maupun penelitian. Dapat dilihat dari definisi tersebut bahwa pendidikan berupa pelatihan dan pengajaran. Hal tersebut mengindikasikan bahwa dalam pendidikan diperlukan interaksi antara orang yang lebih menguasai ilmu dengan orang yang membutuhkan ilmu. Praktik tersebut jika dalam ranah formal terjadi di institusi pendidikan dimana adanya kegiatan belajar yang dilakoni oleh murid dan mengajar yang dilakoni oleh guru atau dosen.

Guru merupakan aspek penting guna menjamin keberhasilan pendidikan. Hal ini dikarenakan guru terlibat langsung dalam kegiatan belajar mengajar. Sejalan dengan yang diungkapkan oleh Mahatma Gandhi (Rani, 2010) bahwa buku paling benar bagi muridnya adalah guru. Guru yang berkualitas akan menciptakan sumber daya manusia yang unggul guna menompang kebutuhan nasional terhadap pemenuhan sumber daya manusia berkualitas. Namun harapan tersebut tidak akan tercapai jika dalam dunia pendidikan masih dapat ditemukan berbagai masalah. Salah satu masalah di dunia pendidikan adalah ketidakadilan dalam dunia kerja bagi guru honorer. Hal tersebut diindikasikan dengan kehidupan guru honorer yang sangat jauh dari kata sejahtera. Bagaimana mungkin gaji bagi seseorang yang memanusiakan manusia jauh lebih kecil jika dibandingkan seorang engginer pembuat sebuah robot yang fungsinya belum mendekati kemampuan manusia. Pembanding lain yang lebih relevan adalah guru honorer dan guru PNS yang memiliki tanggung jawab dan beban kerja yang relatif sama menunjukan perbedaan pendapatan yang jomplang. Sebagian besar guru honorer di Indonesia memiliki gaji yang jauh dibawah upah minimum daerah, padahal peran guru honorer di sekolah sangatlah penting. Selain itu sebagian besar sekolah di Indonesia komposisi guru honorer lebih banyak dibandingkan guru PNS di tiap sekolah.

Di sisi lain dengan disetujuinya Permenpan-RB Nomor 27 Tahun 2021 mengatur tentang Pengadaan Pegawai Negeri Sipil (PNS) serta Permenpan-RB Nomor 28 Tahun 2021 mengatur tentang Pengadaan Pegawai Pemerintah dengan Perjanjian Kerja (PPPK) untuk Jabatan Fungsional Guru pada Instansi Daerah mengindikasikan bahwa tes CASN tahun 2021 tidak ada pengangkatan PNS baik bagi sarjana pendidikan maupun guru honorer. Menteri Kemendikbud Nadiem Makarim mengindikasikan bahwa seleksi CPNS bagi guru akan ditiadakan untuk beberapa tahun kedepan dengan berbagai pertimbangan. Selain itu seleksi PPPK menjadi perdebatan baru dalam pelaksanaannya, dimana guru honorer dengan usia lebih dari 40 tahun diharuskan berkompetisi dengan guru honorer yang berusia muda. Serentetan permasalahan tersebut mengindikasikan bahwa perlakuan pemerintah terhadap guru honorer jauh dari nilai keadilan dan Hak Asasi Manusia. 


\section{METODE}

Penelitian ini merupakan riset kepustakaan (library research). Riset kepustakaan atau studi pustaka merupakan serangkaian kegiatan yang berkenaan dengan metode pengumpulan data pustaka, membaca dan mencatat serta mengolah bahan penelitian (Zed, 2008). Metode penelitian kepustakaan memungkinkan peneliti mendapatkan data empirik maupun informasi yang telah dikumpulkan oleh peneliti lain sebelumnya, baik berupa laporan ilmiah, laporan hasil penelitian, dan buku tanpa harus meneliti secara langsung di lapangan. Adapun tahap-tahap dalam penelitian ini adalah mengumpulkan bahan-bahan penelitian berupa jurnal baik nasional maupun internasional, buku, dan perundangundangan yang mendukung kata kunci mengenai guru, keadilan, dan hak asasi manusia; membaca bahan penelitian; membuat catatan penelitian; dan mengolah catatan penelitian. Dikarenakan sumber data dan hasil data yang diolah dalam studi pustaka berbentuk deskripsi, maka penelitian ini menggunakan pendekatan kualitatif. Metode kualitatif digunakan untuk mendapatkan data yang mendalam, suatu data yang mengandung makna (Sugiono, 2012). Maka dari itu penelitian ini akan mencoba menggali makna dari informasi maupun data empirik yang didapat dari buku-buku, hasil laporan penelitian ilmiah maupun dari literatur yang lain. Sumber data yang menjadi acuan adalah buku, data sekunder, observasi, dan perundang-undangan yang terkait dengan isu penelitian dengan buku acuan utama adalah $A$ Theory of Justice hasil pemikiran John Rawls.

Sedangkan paradigma dasar yang dianut adalah Justice as Fairness dan keadilan sosial yang dikemukakan oleh John Rawls dalam bukunya A Theory of Justice (1971). Sedangkan definisi keadilan menurut beberapa ahli merupakan hal utama, bagaimanapun orang lain berkehendak tuntutan keadilan lebih besar daripada kepentingan moral dan dan politik (baik, bahagia, benar) (Sandel, 1984). Keadilan adalah kebajikan pertama dari sebuah intstitusi sosial, keadilan merupakan kebenaran dari sebuah sistem pemikiran (Rawls, 1971). Apapun yang muncul dari situasi yang adil dari langkahlangkah adil, adalah keadilan (Lebacqz, 1986). Selain keadilan, penelitian ini juga menyoroti Hak Asasi Manusia sebagai kaidah penguat analisis etis, dijabarkan kedalam berbagai pandangan mengenai Hak Asasi Manusia baik menurut ahli, maupun perundang-undangan yang terkait dengan Hak Asasi Manusia.

\section{HASIL DAN DISKUSI}

\section{Deskripsi Konteks Guru Honorer di Indonesia}

Berdasarkan PP Nomor 48 Tahun 2005 tenaga honorer adalah seseorang yang diangkat oleh pejabat pembina kepegawaian atau pejabat lain dalam pemerintahan untuk melaksanakan tugas tertentu pada instansi pemerintahan. Sebagian besar masalah yang dialami guru honorer adalah bersumber dari pendapatan yang tidak sepadan dengan beban kerja dan status pendidikan. Sebelum menganalisis lebih jauh alangkah baiknya mengetahui relaita kehidupan guru honorer di Indonesia. Sebagian besar deskripsi realita ini merupakan hasil wawancara, observasi secara langsung selama satu dekade, dan beberapa isu yang mencuat ke permukaan pada tahun-tahun terakhir. Dengan gaji per 
bulan kurang lebih tiga ratus ribu rupiah, guru dituntut untuk melakukan berbagai perkerjaan seperti mengajar sebagai tugas pokok, administratif, akreditasi, asesmen, pelatihan kompetensi guru, dan berbagai kegiatan diluar kegiatan belajar mengajar seperti menjadi pembina ekstrakulikuler. Hal tersebut memunculkan sebuah pertanyaannya apakah cukup dengan gaji sekian untuk menghidupi diri atau bahkan keluarga dalam satu bulan? Kondisi lain yang menjadi dilema adalah sebagian besar sekolah di Indonesia membagikan gaji kepada guru honorer berdasarkan pencairan dana Bantuan Operasional Sekolah (BOS) yaitu tiga bulan sekali. Dapat dibayangkan dengan gaji sekian dan dibagikan setiap tiga bulan sekali, bagaimana guru honorer dapat bertahan hidup? Pertanyaan tersebut mungkin terkesan berlebihan namun cukup logis jika melihat perkembangan ekonomi di Indonesia dengan tingkat inflasi yang cukup tinggi disetiap tahunnya. Kata "berkah" selalu menjadi jawaban diplomatis guru honorer ketika disinggung mengenai gaji mereka yang rendah. Moto dari Kementrian Agama "ikhlas beramal" secara tidak langsung diadopsi oleh sebagian besar guru honorer yang bernaung di bawah Kementrian Pendidikan dan Kebudayaan.

Terlalu jauh jika membandingkan gaji guru honorer seorang yang memanusiakan manusia dengan gaji engginer seorang yang membuat sebuah robot yang mendekati kemampuan manusia. Pertama kita bisa membandingkan dengan gaji UMP terendah di Indonesia. Berdasarkan data Kementrian Tenaga Kerja gaji UMP terendah di Indonesia tahun 2021 adalah Provinsi DIY yakni sebesar Rp.1.765.0. Jika dibandingkan dengan gaji guru honorer mungkin sekitar satu per enam dari UMP Provinsi DIY. Hal tersebut tentu saja akan menjadi daya tidak tarik bagi generasi-generasi muda yang potensial untuk terjun kedalam dunia pendidikan khususnya di sekolah. Time is money dipopulerkan oleh Deng Xiaoping dan diperhalus menjadi kata "realistis" mungkin menjadi pegangan generasi-generasi muda ditengah era globalisasi yang semakin hari semakin menuntut kemampuan finansial. Dalam hal ini Kemendikbud (2021) mengkonfirmasi bahwa rendahnya skor PISA negara Indonesia dengan berada pada posisi 74 dari 79 negara anggota OECD salah satunya diakibatkan oleh kualitas pendidik (guru) yang rendah, sehingga menyebabkan efek domino terhadap rendahnya kualitas sumber daya manusia di Indonesia. Kualitas guru yang rendah tersebut kembali lagi bahwa banyak generasi muda potensial yang tidak minat terhadap dunia pendidikan, serta rendahnya produktivitas guru honorer di Indonesia dikarenakan gaji yang sangat rendah untuk seorang sarjana.

Kata sarjana mulai disentuh dalam kajian ini karena memang gaji seorang guru tanpa label sarjana pun sangat jauh dari dari UMP terendah di Indonesia. Padahal sebagian besar alasan individu meneruskan kuliah selain mencari ilmu adalah meneruskan karir dan kehidupan yang layak (Fadilah et al, 2019). Seiring berjalannya waktu jumlah guru honorer di Indonesia terus meningkat, bahkan tak sedikit guru honorer yang sudah berusia lanjut. Berdasarkan data KemenpanRB (2021) data guru THK-II adalah sebanyak 129.938 orang. Jumlah tersebut tentu saja bukan jumlah yang sedikit, mereka telah mengabdi selama lebih dari satu dekade. Dengan gaji yang sedikit, terdapat berbagai alasan mengapa mereka terus betahan mengabdikan diri untuk mencerdaskan anak bangsa. Alasan tersebut antara lain kecintaan mereka terhadap anak-anak, keinginan untuk mencerdaskan anak 
bangsa, dan tentu saja dengan harapan diangkat menjadi abdi negara atau biasa dikenal Pegawai Negeri Sipil (PNS). Namun harapan tersebut kembali memudar ditengah kebijakan pemerintah yang kurang memihak guru honorer di Indonesia.

Permenpan-RB Nomor 27 Tahun 2021 mengatur tentang Pengadaan Pegawai Negeri Sipil (PNS) serta Permenpan-RB Nomor 28 Tahun 2021 mengatur tentang Pengadaan Pegawai Pemerintah dengan Perjanjian Kerja (PPPK) untuk Jabatan Fungsional Guru pada Instansi Daerah mengindikasikan bahwa tes CASN tahun 2021 tidak ada pengangkatan PNS baik bagi sarjana pendidikan maupun guru honorer. Menteri Kemendikbud Nadiem Makarim mengindikasikan bahwa seleksi CPNS bagi guru akan ditiadakan untuk beberapa tahun kedepan dengan berbagai pertimbangan. Dari kebijakan tersebut maka harapan bagi guru honorer di Indonesia untuk menjadi PNS menghilang untuk beberapa tahun kedepan. PNS memang menjadi salah satu tujuan utama bagi sebagian besar guru honorer di Indonesia. Dengan kegiatan beban kerja yang relatif sama, setidaknya guru dapat mendapatkan gaji, tunjangan keluarga, dan tunjangan di hari tua guna menyongsong kehidupan yang lebih layak.

Tidak adanya kontrak yang panjang dengan maksimal 5 tahun minimal 1 tahun, dan tidak adanya tunjangan di hari tua menjadi faktor pembeda antara guru PNS dan guru PPPK. Meskipun demikian PPPK ini merupakan separuh jawaban dari harapan guru honorer untuk kehidupan lebih layak dengan gaji yang cukup menjanjikan atau sekitar sepuluh kali lipat gaji guru honorer. Namun dalam praktiknya seleksi PPPK menjadi perdebatan baru dalam pelaksanaannya, dimana guru honorer dengan usia lebih dari 40 tahun diharuskan berkompetisi dengan guru honorer yang berusia muda. Guru honorer berusia lanjut mengeluhkan hal tersebut, mereka merasa tidak mampu jika harus bersaing skor dengan anak-anak muda dalam seleksi PPPK. Kemendikbud dalam hal ini hanya memberikan skor tambahan yang tidak signifikan sebagai bentuk afirmasi bagi guru yang telah mengabdi selama puluhan tahun, bahkan ada dari mereka telah berusia lebih dari 50 tahun. Padahal yang sebenarnya mereka inginkan adalah pengangkatan secara langsung tanpa seleksi sebagai bentuk penghargaan terhadap guru honorer yang telah mengabdi selama puluhan tahu. Dalam hal ini pemerintah berdalih dengan mengadakan seleksi PPPK sebanya 3 kali dalam satu tahun. Hal tersebut positif jika diadakan pada kondisi normal, namun masa pandemi memaksa pelaksanaan seleksi PPPK dilakukan dengan protokol kesehatan yang ketat. Dapat menjadi perhatian seorang guru honorer dengan pengabdian puluhan tahun diharuskan melakukan swab selama 3 kali berturut-turut jika mereka gagal pada seleksi tahap 1 dan tahap 2 hanya demi menjadi ASN di sisa masa mengajar sebagai ASN yaitu usia 60 tahun. Berbagai deskripsi tersebut menunjukan bahwa ada suatu isu/kondisi yang jelas meluap ke permukaan namun belum mendapatkan perhatian, dan penangangan yang semestinya yaitu isu ketidakadilan bagi guru honorer.

\section{Urgensi Peran Guru dalam Pembangungan}

Pada bagian ini membahas mengenai seberapa penting peran guru baik bagi siswa, bagi 
pendidikan, maupun terhadap pembangunan suatu negara. Banyak pihak yang berasumsi bahwa guru yang berkualitas akan mencetak peserta didi yang bekualitas. Faktanya memang hal tersebut benar adanya diperkuat dengan penelitian yang dilakukan oleh Goldhaber \& Anthony (2003) dan Seebruck (2015) bahwa pendidikan dapat ditingkatkan dengan mengembangkan kualitas guru sehingga dapat meningkatkan kinerja peserta didik. Penelitian lain juga dilakukan oleh Azam \& Kingdon (2014) dengan menyoroti hubungan antara kualitas guru dengan hasil belajar siswa di salah satu sekolah swasta di India. Selain memiliki peran terhadap peningkatan pendidikan, kinerja peserta didik, dan hasil belajar siswa. Peran guru juga ternyata sangat penting dalam praktik pembangunan suatu negara. Negara-negara yang tergabung dalam BRICS (Brazil, Rusia, India, China, South Africa) mengkonfirmasi bahwa dominasi ekonomi, politik, demografi, dan perkembangan pesat yang mereka alami adalah hasil dari investasi mereka terhadap pendidikan (Yuan, 2003). Dengan sumber daya utama dari sektor pendidikan negara BRICS adalah guru (Kumar, \& Wiseman, 2021). Secara spesifik India dengan tegas mengadopsi dasar pemikiran Mincer (1981) mengenai teori modal manusia, dengan berinvestasi besar terhadap kualitas guru. India percaya hal tersebut akan memberikan efek domino dimana guru berkualitas akan maka akan memberi efek terhadap kinerja siswa, peningkatan lapangan kerja, lalu peningkatan produktivitas, dan berakhir pada peningkatan status nasional.

Berdasarkan hasil obeservasi banyak pihak di Indonesia nampaknya belum menyadari pentingnya peran guru dalam pembangungan suatu negara. Caine Rolleston \& Lee Crawfurd (2020) melakukan penelitian dengan menyoroti secara spesifik bagaimana efek jangka panjang guru di negara berkembang seperti Ethiopia dan Vietnam. Penelitian tersebut menemuka sebuah fakta menarik bahwa memiliki guru kelas 5 yang lebih profesional akan menghasilkan nilai ujian yang lebih baik di kelas 10. Selain itu 20 siswa yang diajar oleh guru profesional berpotensi memperolah total kumulasi tambahan PBD per kapita sebesar \$720 dari total keseluruhan PDB Vietnam \$6000 per kapita. Hal tersebut tersebut menunjukan bahwa dengan meningkatkan investasi terhadap guru akan memberikan potensi ekonomi yang lebih besar jika dibandingkan dengan investasi di beberapa sektor ekonomi secara langsung.

\section{Kajian Etis terhadap Isu Guru Honorer di Indonesia}

Berbeda dengan pemaparan sebelumnya cenderung menyoroti ketidakadilan berdasarkan data. Pada bagian ini pembahasan menyisipkan sebuah prinsip keadilan terhadap data di lapangan tentang guru honorer. John Rawls dalam bukunya A Theory of Justice (1971) mendefinisikan keadilan adalah kebajikan pertama dari sebuah intstitusi sosial, keadilan merupakan kebenaran dari sebuah sistem pemikiran. Berdasarkan definisi tersebut dapat digarisbawahi bahwa keadilan merupakan kebajikan utama dalam sebuah institusi. Menimbulkan sebuah perhatian baru apakah Kemendikbud sebagai intitusi yang menaungi guru honorer di dalam dunia pendidikan sudah bersikap adil.

Pada pembahasan sebelumnya gaji honorer dibandingkan dengan sesama tenaga kerja yaitu engginer, dan UMP DIY 2021. Sedangkan pada pembahasan kali ini perbandingan akan lebih aple to 
aple dengan membandingkan gaji guru honorer dengan gaji guru PNS. Pada dasarnya hak dan kewajiban baik guru honorer maupun guru PNS hampir sama, yaitu memiliki hak mendapatkan honorarium perbulan, mendapatkan cuti berdasarkan Undang-Undang Ketenagakerjaan, dan mendapatkan perlindungan hukum. Sedangkan kewajiban sebagai guru adalah melaksanakan tugas kegiatan belajar mengajar, melaksanakan tugas administrasi, melaksankan ketentuan yang berlaku di sekolah, dan mematuhi ketentuan dalam surat perjanjian kerja (Mulyasa, 2006). Namun yang menjadi perbedaan utama adalah guru PNS memiliki tugas mengajar yang lebih spesifik sesuai SK yang diterima, sedangkan guru honorer justru lebih fleksibel dalam artian mengisi berbagai kelas yang kosong. Karena memang berdasarkan observsasi di lapangan guru honorer dan guru PNS relatif memiliki tugas yang sama. Jika membandingkan gaji honorer dengan gaji guru PNS, kurang lebih gaji PNS delapan kali lebih besar dari guru honorer. Bahkan gaji PNS jika sudah bersertifikat pendidik bisa berkali kali lipat dengan jaminan tunjangan di masa tua.

Dalam menyikapi hal tersebut alangkah baiknya mengetahui konsepsi keadilan sosial yang dikemukakan oleh Rawls (1971) bahwa keadilan sosial merupakan bentuk kerjasama sosial berkelanjutan dari generasi ke generasi berikutnya. Ikatan kerjasama sosial berdasarkan pada identitas kepentingan bahwa kehidupan yang lebih baik dimungkinkan daripada yang bisa didapatkan jika setiap orang berusaha mencukupi kebutuhan sehari-hari. Hal tersebut menunjukan bahwa kerjasama sosial tumbuh karena ada kebutuhan dan kepentingan bersama. Namun jika dalam kerjasama sosial tersebut juga tidak sepenuhnya berjalan baik dikarenakan konflik kepentingan dan tidak ada kesepakatan dalam hal bagaimana hasil kerjasama sosial dibagi atau didistribusikan. Maka seperangkat prinsip keadilan dibutuhkan untuk mengatur cara bagaimana lembaga sosial/institusi untuk mendistribusikan hasil kerjasama dengan adil. Dalam hal ini Kemendikbud sebagai institusi pendidikan kurang dapat mendistribusikan hasil kerjasama dengan dengan baik, sehingga menimbukan konflik kepentingan berupa masalah keadilan sosial. Rawls (1971) memandang masalah keadilan sosial sebagai circumstances of justice, yaitu sebuah kondisi dimana kerjasama sosial tersebut diperlukan prinsip-prinsip keadilan yang mengatur hak, kewajiban, keuntungan, dan beban hasil kerjasama sosial secara adil kepada masyarakat.

Secara keseluruhan terdapat dua kosepsi prinsip keadilan sosial menurut John Rawls (1971) yaitu konsepsi umum dan konsepsi khusus. Prinsip pokok dalam konsepsi umum menitikberatkan kepada equality atau persamaan, persamaan distribusi nilai primer, dan ketidaksamaan tersebut dapat ditoleransi sejauh menguntungkan semua pihak. Pada palagraf sebelumnya dideskripsikan bahwa ada dua subjek yang memiliki persaamaan beban kerja yang sama yaitu guru honorer dan guru PNS, namun distribusi nilai primer berupa gaji menunjukan ketidaksamaan. Adapun ilustrasi dari pendekatan ini termuat pada gambar 1 di bawah ini. 


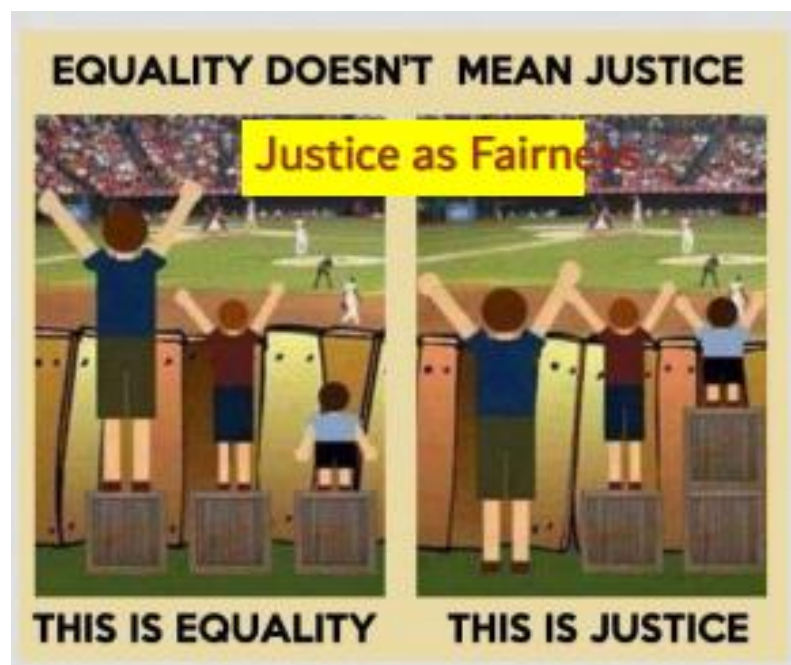

Gambar 1. Ilustrasi Justice as Fairness

Rawls tidak mengklaim bahwa orang benar-benar setuju dengan seperangkat prinsip keadilan tertentu yang dapat dipertahankan secara moral. Sebaliknya orang-orang akan menyetujui prinsipprinsip tersebut dalam kondisi tertentu. Kondisi yang dialami guru honorer inilah yang membuat banyak pihak setuju bahwa diperlukan prinsip keadilan dalam menjamin hak dan kewajibannya. Dalam hal ini prinsip primary goods menjadi titik perhatian dikarenakan sebuah prinsip yang secara spesifik mendefinisikan nilai material maupun nonmaterial yang dapat mempengaruhi kehidupan dan masa depan individu.

Dalam konsepsi khusus keadilan, John Rawls (1971) membagi menjadi dua prinsip keadilan sosial. Prinsip pertama setiap orang memiliki kebebasan yang luas. Prinsip kedua ketimpangan ekonomi dan sosial didata sehingga memberikan keuntungan yang besar bagi kelompok yang lemah, berbagai jabatan dan posisi terbuka bagi semua orang dalam kondisi kesetaraan peluang yang fair. Dalam hal ini prinsip keadilan diperlukan untuk menyoroti ketimpangan gaji (ekonomi) diantara guru honorer dan guru PNS. Pada kalimat selanjutnya prinsip keadilan diterapkan untuk memberikan keuntungan bagi kaum yang lemah, guru honorer sebagai kaum yang lemah tentu harus diberikan perhatian. Sebagai kaum yang lemah guru honorer justru menjadi garda terdepan dalam mengambil berbagai tanggung jawab di sekolah dengan tidak terpenuhinya prinsip primary goods. Dengan gaji sekian tentu saja akan mempengaruhi guru honorer dan keluarganya di masa depan. Pada gambar 1 kurang lebih mempresentasikan realita bahwa dengan beban kerja yang sama guru honorer tidak dapat mendapatkan berbagai akses ekonomi, bahkan jabatan dimana sebagian besar guru honorer mendapatkan jabatan hanya di sekolah-sekolah swasta saja. Maka dari itu Kemendikbud sebagai intitusi yang menaungi guru honorer menciptakan sebuah kondisi circumstances of justice dimana diperlukan penerapan-penerapan prinsip-prinsip keadilan sosial untuk menciptakan kerjasama sosial, serta pendistribusian nilai-nilai primer yang adil.

\section{Kajian Hukum dan HAM terhadap Isu Guru Honorer di Indonesia}

Hak Asasi Manusia merupakan hak mutlak (absolute) yakni hak yang memberikan wewenang 
kepada seseorang atau individu untuk melakukan sesuatu perbuatan hak mana dapat dipertahankan oleh siapapun, sehingga hak asasi manusia merupakan hak yang melekat (inheren) pada individu yang bersifat mutlak (Kansil, 1986). Dalam berbagai pemaparan sebelumnya banyak disinggung mengenai hak guru honorer, yang selanjutnya akan dibahas bagaimana hukum dan HAM berperan dalam melindungi hak warga negaranya khususnyaa terhadap perlindungan hak guru honorer di Indonesia. Peraturan mengenai HAM di Indonesia termuat dalam Undang-Undang Nomor 39 Tahun 1999 tentang Hak Asasi Manusia merupakan bentuk tanggung jawab Indonesia sebagai negara demokrasi dan anggota PBB (Smith et al, 2008). Adapun pasal-pasal dalam Undang-Undang Nomor 39 Tahun 1999 yang terkait dengan pembahasan guru honorer antara lain: Pasal 28 A "setiap orang berhak untuk hidup"; pasal 28 C (1) "setiap orang berhak untuk pengembangan diri"; pasal 28 C (2) "setiap orang berhak untuk memajukan dirinya dalam memperjuangkan haknya secara kolektif untuk membangun masyarakat"; pasal 28 D (2) "setiap orang berhak untuk bekerja sera mendapat imbalan dan mendapat perlakuan yang adil dan layak dalam hubungan kerja." Hal tersebut mempertegas bahwa guru honorer memiliki hak untuk kehidupan yang layak, memiliki hak untuk menuntut perlakuan yang adil di dunia kerja. Pasal-pasal tersebut menjadi penguat, dan alasan yang valid dari berbagai perjuangan guru honorer di Indonesia untuk mendapatkan apa yang seharusnya mereka dapatkan. Hal ini dikarenakan HAM merupakan katalis bagi kreatifitas masyarakat untuk bergerak maju (Grady, 1979).

Selain Undang-Undang mengenai HAM, keadilan dalam dunia kerja juga diatur dalam UndangUndang Republik Indonesia Nomor 13 Tahun 2003 Tentang Ketenagakerjaan. Dalam pasal 88 ayat 1, 2, dan 3 secara berurutan berbunyi "Setiap pekerja/buruh berhak memperoleh penghasilan untuk memenuhi penghidupan yang layak bagi manusia; Pemerintah menetapkan kebijakan pengupahan yang melindungi pekerja/buruh; Kebijakan pengupahan yang dimaksud adah pengupahan (a) Upah minimum, (b) Upah kerja lembur, (c) Upah tidak masuk kerja karena berhalangan, (d) Upah tidak masuk kerja karena ada kegiatan lain diluar pekerjaannya, (e) Upahkarena menjalankan hak waktu istirahat kerjanya, (f) Bentuk dan cara pembayaran upah, (g) Denda dan potongan upah, (h) Hal-hal yang dapat diperhitungkan dengan upah, (i) Struktur dan skala pengupahan yang proporsional, (j) Upah untuk pembayaran pesangon, dan (k) Upah untuk perhitungan pajak penghasilan”. Upah minimum yang dimaksud dijelaskan pada pasal 89, secara garis besar yakni upah berdasarkan wilayah seperti UMK, UMP, dan UMR. Sebagaimana yang telah dibahas pada pembahasan sebelumnya dalam PP Nomor 48 Tahun 2005 tenaga honorer adalah seseorang yang diangkat oleh pejabat pembina kepegawaian atau pejabat lain dalam pemerintahan untuk melaksanakan tugas tertentu pada instansi pemerintahan. Dengan demikian dapat disimpulan bahwa gaji yang diterima guru honorer selain tidak adil secara pendekatan etis, tidak adil juga secara hukum karena tidak terpenuhinya standar gaji yang diterima sesuai perundang-undangan. 


\section{KESIMPULAN}

Berdasarkan hasil pembahasan terhadap isu permasalahan keadilan yang dialami oleh guru honorer di dalam dunia kerja, terdapat beberapa poin yang mejadi perhatian. Pertama adalah Kemendikbud sebagai lembaga yang menaungi guru honorer menciptakan sebuah kondisi circumstances of justice dimana diperlukan penerapan prinsip-prinsip keadilan sosial untuk menciptakan kerjasama sosial, serta pendistribusian nilai-nilai primer yang adil sehingga tidak menimbulkan ketimpangan ekonomi dan dapat terpenuhinya kehidupan yang layak bagi guru honorer. Kedua guru honorer sebagai kaum yang lemah tentu harus diberikan perhatian. Sebagai kaum yang lemah guru honorer justru menjadi garda terdepan dalam mengambil berbagai tanggung jawab di sekolah sehingga harus diperhatikan agar terpenuhinya prinsip primary goods. Ketiga Kemendikbud dan Pemerintah harus menjamin keadilan bagi guru honorer dengan mengatasi ketimpangan ekonomi dan sosial guna mendapatkan kehidupan yang lebih layak. Keempat perangkat hukum dan HAM dapat menjadi dasar bagi honorer untuk terus memperjuangkan haknya sebagai tenaga kerja yang penting bagi pembangunan negara Indonesia. Hal ini dikarenakan banyak penelitian yang telah membuktikan bahwa kualitas guru berkorelasi dengan peningkatan kinerja peserta didik, peningkatan pendidikan, dan peningkatan SDM guna menompang pembangunan suatu negara.

Saran yang diusulkan dalam penelitian ini adalah pemerintah harus mempermudah proses perekrutan Aparatur Sipil Negara bagi guru honorer yang telah memiliki masa kerja yang memadai. Pemerintah harus memperketat profesionalitas guru sehingga guru menjadi prospek kerja yang penting dan menjanjikan bagi generasi muda di masa depan. Selain itu pemerintah harus memenuhi hak guru honorer mendapatkan gaji yang layak dan sesuai dengan perundang-undangan dengan memisahkan dana anggaran khusus bagi guru honorer. Dan yang terakhir jika menyoroti prinsip keadilan poin utamanya adalah adanya keseimbangan diatara pemenuhan hak dan pelaksanaan kewajiban. Jika pemerintah tidak siap secara finansial untuk memenuhi hak material bagi guru honorer, pemererintah lebih baik menyesuaikan dan mengefisienkan kewajiban dari tugas guru honorer, namun masih mendapatkan peluang yang besar untuk menjadi ASN. Hal ini dikarenakan ada beberapa syarat yang mengharuskan calon ASN minimal 2 tahun untuk mendapatkan NUPTK sebagai syarat perekrutan PPPK, minimal masa kerja 5 tahun untuk mengikuti Program Profesi Guru dalam jabatan. Kajian ini mengusulkan syarat-syarat tersebut dihapuskan sehingga porsi guru honorer dapat menjadi sebuah pekerjaan freelance. Hal tersebut dapat memberikan keleluasaan bagi guru honorer, dan mendapatkan waktu yang banyak di luar sekolah guna memenuhi kebutuhan perekonomian keluarganya di tengah era globalisasi yang sangat menuntut kemapanan secara finansial.

\section{REFERENSI}

Azam, M., \& Kingdon, G. G. (2015). Assessing teacher quality in India. Journal of Development Economics, 117, 74-83. 
Crawfurd, L., \& Rolleston, C. (2020). Long-run effects of teachers in developing countries. Review of Development Economics Wiley Online Library, 1-21. DOI: 10.1111/rode.12717

Fadilah, A., Sujana., \& Sukartaatmaja, I. (2019). Kajian Minat Studi Lanjut Siswa SMA/SMK Kota Bogor ke Perguruan Tinggi. JAS-PT (Jurnal Analisis Sistem Perguruan Tinggi), 3(1), 53-56.

Goldhaber, D., \& Anthony, E. (2003). Teacher quality and diversity series. (ED 477271). ERIC. http://files.eric.ed.gov/fulltext/ED477271.pdf

Kansil, CST. (1986). Pengantar Ilmu Hukum Data Hukum Indonesia. Jakarta: Balai Pustaka.

Kementrian Ketenagakerjaan. (2021). Data Upah Minimun Provinsi 2021, (Online), (www.kemnaker.go.id), diakses 9 Desember 2021.

Kementrian Pendayagunaan Aparatur Negara dan Reformasi Birokrasi, Permenpan-RB Nomor 27 Tahun 2021 tentang Pengadaan Pegawai Negeri Sipil (PNS).

Kementrian Pendayagunaan Aparatur Negara dan Reformasi Birokrasi, Permenpan-RB Nomor 28 Tahun 2021 mengatur tentang Pengadaan Pegawai Pemerintah dengan Perjanjian Kerja (PPPK) untuk Jabatan Fungsional Guru pada Instansi Daerah.

Kementrian Pendayagunaan Aparatur Negara dan Reformasi Birokrasi. (2021). Data Guru THK-II, (Online), (www.menpan.go.id), diakses 9 Desember 2021.

Kementrian Pendidikan dan Kebudayaan. (2020). Rencana Strategis Kementrian Pendidikan dan Kebudayaan 2020-2024. Jakarta: Kemendikbud.

Kumar, P., \& Wiseman, A. W. (2021). Teacher Quality and Education Policy in India: Understanding the Relationship Between Teacher Education, Teacher Effectiveness, and Student. Newyork and London: Routledge Taylor \& Francis Group.

Lebacqz, K. (1986). Six Theories of Justice. United States: Augsburg Fortress.

Mincer, J. (1981). Human capital and economic growth (Working Paper No. 803). Cambridge, MA: National Bureau of Economic Research. Retrieved from http://www4.fe.uc.pt/mapsd/mincer_w0803.pdf.

Mulyasa, E. (2006). Menjadi guru profesional. Bandung: PT. Remaja Rosdakarya.

Rani, G. (2010). Changing landscape of higher education in India: The case of engineering education in Tamil Nadu. (Working Paper No. 36). doi:10.4016/9522.01

Rawls, J. (1971). A Theory of Justice. London: Harvard University Press.

Republik Indonesia, Peraturan Pemerintah Nomor 48 Tahun 2005 tentang Pengangkatan Tenaga Honorer Menjadi Calon Pegawai Negeri Sipil.

Republik Indonesia, Undang -Undang Dasar Negara Republik Indonesia Tahun 1945.

Republik Indonesia, Undang -Undang Republik Indonesia Nomor 13 Tahun 2003 Tentang Ketenagakerjaan.

Republik Indonesia, Undang-Undang Nomor 39 Tahun 1999 tentang Hak Asasi.

Sandel, M. (1984). Liberalism and the Limits of Justice. London: Oxford Press. 
Seebruck, R. (2015). Teacher quality and student achievement: A multilevel analysis of teacher credentialization and student test scores in California high schools. McGill Sociological Review, 5, 1-18. https://www.mcgill.ca/msr/msr-volume-5/teacherquality-and-student-achievement.

Smith, et al. (2008). Hukum Hak Asasi Manusia. Yogyakarta: PUSHAM UII.

Sugiyono. (2012). Metode Penelitian Pendidikan. Bandung: Alfabeta.

Yuan, S. (2013). Educational policies and economic growth in BRICS: Comparative perspectives. Knowledge Cultures, 3(1), 32-44.

Zed, M. (2008). Metode Penelitian Kepustakaan. Jakarta: Yayasan Obor Indonesia. 